\title{
Jurist-Diction
}

Volume 4 No. 5, September 2021

\section{Hak Regres Penanggung pada Jaminan Perorangan Dalam Kepailitan}

\author{
Madeleine Celandine \\ mcelandine@gmail.com \\ Universitas Airlangga
}

How to cite:

Madeleine Celandine, 'Hak

Regres Penanggung pada

Jaminan Perorangan Dalam

Kepailitan' (2021) Vol. 4 No. 5

Jurist-Diction.

Histori artikel:

Submit 9 Juli 2021;

Diterima 15 Agustus 2021;

Diterbitkan 1 September 2021

DOI:

10.20473/jd.v4i5.29820

p-ISSN: 2721-8392

e-ISSN: $2655-8297$

\section{Abstract}

The credit agreement as the principal agreement between the debtor and the creditor can acquire additional collateral providing material collateral and individual collateral. Personal collateral for individual rights, which is the agreement of a third party to bind themselves to debtors and creditors involved in credit agreements in accordance with the interests of creditors. In the event that the debtor does not have assets and is unable to repay debts to the creditor, the person responsible for paying the creditors' reserves and is obliged to pay debts to the creditor. The responsibility of the person responsible for compiling the debtor is not carried out by the creditor and the person responsible for the release of their privileges. The guarantor who has agreed to pay the debtor according to the law obtained by the right of regres, namely the right to recover from the payment owned. An interesting discussion about this Guarantee relates to the bankruptcy law regarding the enforcement of the right to regress so that it can be held accountable for receiving payments made.

Keywords: Regress Rights; Personal Guarantee; Bankruptcy.

\section{Abstrak}

Perjanjian kredit sebagai perjanjian pokok antara debitor dengan kreditor dapat melahirkan jaminan tambahan berupa jaminan kebendaan dan jaminan perorangan. Jaminan perorangan melahirkan hak perorangan, yang merupakan persetujuan pihak ketiga untuk mengikatkan diri kepada debitor dan kreditor yang terlibat dalam perjanjian kredit demi kepentingan kreditor. Dalam hal debitor tidak memiliki harta kekayaan dan tidak mampu membayar utang kepada kreditor, maka penanggung berperan sebagai cadangan debitor dan wajib membayarkan utang kepada kreditor. Tanggung jawab penanggung lahir ketika debitor tidak melaksanakan kewajiban kepada kreditor dan penanggung telah melepaskan hak istimewa yang dimiliki. Penanggung yang telah menggantikan pembayaran debitor demi hukum memperoleh hak regres, yaitu hak untuk menuntut kembali atas pembayaran yang dimiliki. Pembahasan yang menarik mengenai jaminan ini berkaitan dengan hukum kepailitan mengenai penegakan hak regres agar dapat diakui sebagai utang untuk dapat memperoleh piutang pembayaran yang telah dilakukan.

Kata Kunci: Hak Regres; Jaminan Perorangan; Kepailitan. 


\section{Pendahuluan}

Perorangan maupun badan hukum ada kalanya mengalami kendala uang untuk membiayai keperluan atau kegiatannya, sehingga dalam mencukupi kebutuhan akan uang dapat dilakukan dengan memperoleh pinjaman baik borrowing, loan, atau credit. Keperluan akan sumber dana dari luar dapat mengandalkan lembaga Perbankan sebagai lembaga financial intermediary yang berperan sebagai perantara bagi pemilik dana dan pihak yang membutuhkan dana, dengan cara menghimpun dana dari masyarakat dalam bentuk simpanan dan menyalurkan kembali kepada masyarakat dalam bentuk kredit. ${ }^{1}$ Pada hubungan pemberian kredit, pihak yang memperoleh pinjaman disebut debitor, dan pihak yang memberikan pinjaman disebut kreditor.

Kata kredit berasal dari Bahasa Latin yaitu "credo" yang memiliki arti kepercayaan. Perjanjian kredit dilakukan berdasarkan persetujuan atau kesepakatan pinjam-meminjam antara debitor dan kreditor untuk mengikatkan diri dalam perjanjian untuk jangka waktu tertentu. Pemberian kredit oleh bank memperhatikan asas kehati-hatian sebagai tahap preventif untuk menyalurkan dana masyarakat kepada debitor. Pelaksanaan menangkal masalah kredit dilakukan dengan analisis kredit untuk menghindari kredit bermasalah dari debitor. Penilaian keditor melalui analisis kredit bertujuan untuk menilai kemampuan calon debitor dalam memenuhi kewajiban di kemudian hari. Analisis kredit untuk memperkirakan tinggi rendah risiko pemberian kredit dinilai dari debitor mampu menerapkan prinsip "The Five C's of Credit Analysis" yang meliputi character (watak), capital (modal), capacity (kemampuan), collateral (agunan), dan condition of economy (kondisi ekonomi).

Di sisi lain, Perjanjian jaminan penanggungan sebagai perjanjian yang bersifat accessoir, yaitu perjanjian tambahan yang dikaitkan dengan perjanjian pokok, perjanjian kredit sebagaimana sesuai dengan Pasal 1821 BW. Pasal 1820 BW memberikan makna bahwa penanggung bukan debitor karena hanya bertindak sebagai penanggung untuk terpenuhinya prestasi dari debitor kepada kreditor, tetapi

${ }^{1}$ Sarah D.L. Roeroe, 'Kewenangan Pihak Ketiga Sebagai Penjamin Dalam Perjanjian Kredit' (2017) 5 Lex Privatium.[2]. 
apabila pada keadaan tertentu debitor tidak melaksanakan kewajiban pemenuhan prestasi kepada kreditor, maka kewajiban dapat beralih kepada penanggung. Penanggung berkewajiban sebagai cadangan debitor berkewajiban membayar utang debitor sesuai jumlah yang diperjanjikan dalam perjanjian penanggungan, dan atas pembayaran yang dilakukan penanggung secara otomatis memperoleh hak regres, yaitu hak untuk menuntut kembali pembayaran yang dilakukan kepada kreditor. Dikaitkan dengan kepailitan yang merupakan sitaan umum atas semua kekayaan debitor pailit dengan tujuan mempercepat proses likuidasi dan membagi kepada semua kreditor dengan memperhatikan hak masing-masing kreditor. ${ }^{2}$ Menimbulkan suatu permasalahan mengenai penanggung yang telah membayar dan memperoleh hak regres tidak diakui sebagai kreditor dan hak regres yang dimiliki tidak diakui sebagai utang, serta upaya hukum yang dapat dilakukan penanggung agar hak regres diakui sebagai utang debitor dan dapat memperoleh piutang. Berdasarkan hal tersebut, maka rumusan masalah dalam penelitian ini adalah:

1. Apakah hak regres penanggung dapat ditegakkan sebagai utang kepada kurator?

2. Apa upaya hukum bagi penanggung agar hak regres yang dimiliki dapat diakui sebagai utang debitor?

Tulisan ini menggunakan pendekatan peraturan perundang-undangan (statute approach) dan pendekatan konseptual (conceptual approach). Pendekatan perundang-undangan dilakukan dengan menelaah semua peraturan perundangundangan yang bersangkutan dengan jaminan penanggungan dan hukum kepailitan. Perturan yang berkaitan dengan topic bahasan adaah Burgerlijk Webtoek Voor Indische (BW) dan Undang-Undang Nomor 37 Tahun 2004 Tentang Kepailitan (UUK). Sedangkan pendekatan konseptual beranjak dari pandangan-pandangan dan doktrin yang berkembang di dalam ilmu hukum. Dengan mempelajari pandangan dan doktrin bertujuan untuk menemukan ide-ide relevan.

${ }^{2}$ M. Hadi Subhan, Hukum Kepailitan, Prinsip, Norma, dan Praktik di Peradilan (Fajar Interpratama Mandiri 2008).[71]. 


\section{Kedudukan Hak Regres Penanggung dalam Kepailitan Debitor}

Kebebasan berkontrak merupakan perwujudan dari kehendak bebas atas pancaran hak asasi manusia yang perkembangannya dilandasi dari liberalisme yang mengangungkan kebebasan individu. ${ }^{3}$ Penerapan kebebasan berkontrak yaitu memberikan kebebasan dalam membuat perjanjian dengan bentuk apapun (tertulis, lisan, scriptless, paperless, auntentik, nonautentik, sepihak, adhesi, standar/baku, dll) serta dengan isi atau substansi yang dikehendaki oleh para pihak. ${ }^{4}$ Perjanjian tersebut harus memenuhi unsur keabsahan sesuai Pasal 1320 BW antara lain yaitu:

1. Kesepakatan. Sepakat mereka yang mengikatkan dirinya;

2. Cakap bagi para pihak yang mengikatkan dirinya;

3. Suatu hal tertentu yang diperjanjian;

4. Suatu sebab yang diperbolehkan.

Syarat 1 dan syarat 2 merupakan syarat subyektif sehingga apabila dilanggar dapat mengakibatkan dapat dibatalkan, sedangkan syarat 3 dan 4 merupakan syarat obyektif yang berakibat hukum yaitu batal demi hukum.

Perjanjian kredit berasal dari perjanjian pinjam meminjam yang merupakan perjanjian yang salah satu pihak memberikan hak mengenai jumlah tertentu barangbarang dengan syarat pihak peminjam akan mengembalikan sejumlah yang sama dan keadaan semula sesuai Pasal 1754 BW. Di sisi lain, perjanjian kredit merupakan perjanjian yang mengacu pada ketentuan perjanjian pinjam meminjam berdasarkan Pasal 1 angka 11 Undang-Undang Nomor 7 Tahun 1992 tentang Perbankan (Lembaran Negara dan Tambahan Lembaran Negara Tahun 1992) sebagaimana diubah dengan Undang-Undang Nomor 10 Tahun 1998 tentang tentang Perubahan Atas Undang-Undang Nomor 7 Tahun 1992 Tentang Perbankan (Lembaran Negara Republik Indonesia Tahun 1998 Nomor 182, Tambahan Lembaran Negara Repubik Indonesia Nomor 3790) mendefinisikan kredit adalah penyediaan uang atau tagihan

\footnotetext{
${ }^{3}$ Trisadini Prasastinah Usanti, dan Leonora Bakarbessy, Buku Refrensi Perbankan Hukum Jaminan (Revka Petra Media 2014).[2].

${ }^{4}$ Agus Yudha Hernoko, Hukum Perjanjian Asas Proporsionalitas dalam Kontrak Komersial (Kencana 2010).[110].
} 
antara bank dengan nasabah atau orang lain pada jangka waktu tertentu diwajibkan melunasi utang dengan pemberian bunga. ${ }^{5}$

Pasal 1131 BW mengatur apabila debitor tidak memenuhi kewajibannya, maka benda bergerak dan tidak bergerak milik debitor menjadi jaminan kredit. Pengaturan jaminan kredit tersebut sebagai jaminan umum sehingga berlaku bagi semua kreditor. Kreditor disini sebagai pemegang jaminan umum tidak memiliki hak untuk diutamakan dalam memperoleh pelunasan.

Di sisi lain terdapat jaminan khusus yaitu jaminan penanggungan dan jaminan kebendaan yang diharapkan dapat mencegah risiko yang timbul di kemudian hari. Eksistensi perjanjian jaminan hadir sebagai perjanjian tambahan dari perjanjian kredit sebagai perjanjian pokok. Dalam hal ini perjanjian jaminan disebut sebagai perjanjian tambahan, ${ }^{6}$ dan karena esensi dari perjanjian adalah pemenuhan perikatan pihak lain yang timbul dari perjanjian pokok, maka terdapat 2 perjanjian.

Jaminan kebendaan adalah jaminan atas benda terntentu milik debitor atau pihak ketiga yang diperuntukan khusus bagi kepentingan kreditor dan melahirkan hak kebendaan. ${ }^{7}$ Hak kebendaan adalah hak mutlak atas suatu benda dan memberikan kekuasaan langsung. Hak kebendaan antara lain gadai, hipotek, hak tanggungan, fidusia, dan resi gudang. Pemegang jaminan kebendaan mempunyai kedudukan yang lebih diutamakan karena didahulukan dalam pelunasan utang dan memegang benda tertentu milik debitor sebagai jaminan.

Berbeda dengan jaminan penanggungan (Borgtocht) yang melahirkan hak perorangan atau hak pribadi yang memberikan kedudukan kreditor sebagai kreditor konkuren. Pelunasan utang pada kreditor konkuren tidak didahulukan dibandingkan dengan kreditor preferen. ${ }^{8}$

Dalam Bahasa Indonesia Borgtocht disebut sebagai penanggungan dimana orangnya disebut borg atau penanggung sebagaimana diatur dalam Pasal 1820

\footnotetext{
${ }^{5}$ Trisadini Prasastinah Usanti, dan Leonora Bakarbessy, Op.Cit.[10].

${ }^{6}$ Sarah D. L. Roeroe, Op.Cit.[10].

${ }^{7}$ ibid.[8].

${ }^{8}$ ibid.
} 
BW sampai Pasal 1850 BW. Pasal 1820 BW mengartikan jaminan penanggungan merupakan persetujuan pihak ketiga demi kepentingan kreditor yang mengikatkan diri untuk memenuhi kepentingan kreditor apabila debitor wanprestasi.

Perjanjian penanggungan tidak lepas dari perjanjian kredit. J. Satrio berpendapat bahwa dalam hubungan antara kreditor dan debitor, sebenarnya penanggung utang berkedudukan sebagai pihak ketiga, namun demikian penanggung utang sukarela mengikatkan diri sebagai debitor cadangan kepada kreditor untuk prestasi yang sama dengan debitor. Dalam menjalankan perannya, penanggung memiliki hak untuk melindungi kepentingan penanggung, yaitu hak untuk menuntut debitor terlebih dahulu, hak untuk membagi utang, hak untuk mengajukan tangkis gugat, dan hak untuk diberhentikan dari penanggungan karena terhalang melakukan subrogasi.

Kewajiban penanggung untuk melunasi utang debitor baru ada saat syarat debitor cidera janji atau wanprestasi dalam perikatan pokok kepada kreditor sesuai Pasal 1258 BW. Peran penanggung utang baru akan muncul setelah debitor tidak memenuhi kewajiban perikatan sebagaimana mestinya. ${ }^{9}$ Sesuai Pasal 1234 BW kewajiban perikatan atau prestasi dapat berupa kewajiban menyerahkan sesuatu, berbuat sesuatu, dan tidak berbuat sesuatu. Ahmadi Miru dan Sakka Pati berpendapat wujud dan pemenuhan prestasi prestasi antara lain: ${ }^{10}$

a. Barang dilakukan dengan menyerahkan;

b. Jasa dilakukan dengan berbuat sesuatu;

c. Tidak berbuat sesuatu dilakukan dengan tidak berbuat sesuatu.

Terdapat beberapa tanggung jawab penanggung utang demi kepentingan kreditor antara lain:

1. Pasal 1829 BW yaitu bahwa dalam hal perkara pailit betanggung jawab menunjuk pengganti diinya baik secara sukarela atau berdasarkan putusan

\footnotetext{
9 Annisa Amalia Rachmah, 'Analisis Yuridsi Pernjaminan Perorangan (Personal Guarantee) pada Kepailitan Perseroan Terbatas’ (2016) 5 Diponegoro Law Jurnal.[6].

${ }^{10}$ Ahmadi Miru, dan Sakka Pati, Hukum Perikatan Penjelasan Makna Pasal 1233 sampai 1456 BW (RajaGrafindo Persada 2008).[5].
} 
hakim dalam hal tidak mampu menjamin pembayaran utang debitor. Apabila penanggung tidak mampu melakukan kewajiban maka kreditor dapat menunjuk penanggung baru. Akan tetapi apabila tidak berhasil maka sesuai Pasal 1830 BW sebagai gantinya melalui putusan hakim yang berkekuatan hukum tetap, debitor atau penanggung memberikan jaminan gadai dan hipotek;

2. Pasal $1831 \mathrm{BW}$ yaitu penanggung utang bertanggung jawab sebagai cadangan ketika debitor tidak mencukupi untuk pelunasan utangnya. Akan tetapi pada ini terdapat pengecualian bagi kreditor untuk menuntut hak kepada penanggung secara langsung;

3. Pasal $1834 \mathrm{BW}$ yaitu penanggung utang ikut bertanggung jawab atas pembayaran utang debitor karena penanggung telah menyetujui kewajiban untuk membayar utang ataupun ganti rugi kepada kreditor bila debitor wanprestasi mengikatkan debitor dipailitkan.

Penjelasan Pasal 2 Ayat (1) UUK dan prinsip Structured Creditors mengklasifikasikan kreditor menjadi 3 macam yaitu kreditor konkuren, kreditor separatis, dan kreditor preferen. Klasifikasi kreditor tersebut berbeda dengan rezim hukum perdata umum yang mengenal kreditor preferen yang mencakup kreditor memiliki hak jaminan kebendaan dan kreditor yang yang menurut undang-undang harus didahulukan dalam pembayarannaya. Sedangkan hukum kepailitan yang mengenal kreditor separatis yaitu kreditor yang memiliki jaminan kebendaan, ${ }^{11}$ kreditor preferen yaitu kreditor yang menurut undang-undang harus didahulukan pembayarannya daripada kreditor konkuren, dan kreditor konkuren yang tidak memiliki jaminan kebendaan maupun hak istimewa.

Kreditor separatis adalah kreditor yang memegang jaminan kebendaan dapat berupa hak gadai, hipotek, fidusia, hak tanggungan, dan resi gudang ${ }^{12}$ yang memberikan hak penuh kepada kreditor atas suatu hak kebendaan spesifik. Debitor memberikan jaminan kebendaan sebagai jaminan pembayaran utang dengan tujuan

\footnotetext{
${ }^{11}$ M. Hadi Subhan, Op.Cit.[33].

12 Trisadini Prasastinah Usanti dan Leonora Bakarbessy, Op.Cit.[34].
} 
manakala utang telah jatuh tempo, kreditor dapat menuntut eksekusi atas benda yang dijaminkan. ${ }^{13}$

Kreditor preferen adalah kreditoryang diberi keistimewaan dalam pembayaran piutang sebagaimana diatur pada Pasal 1139 BW mengenai privelege khusus dan Pasal 1149 BW mengenai privelege umum. Piutang kreditor preferen adalah sebutan tagihan yang meliputi tagihan pajak, biaya lelang, dan sebagainya yang menurut undang-undnag wajib didahulukan pembayarannya sebagaimana diatur menurut Pasal 60, Pasal 168 juncto Pasal 189 Ayat (1) UUK. ${ }^{14}$

Sedangkan kreditor konkuren adalah kreditor yang tidak memiliki hak jaminan kebendaan atau hak untuk didahulukan. Golongan kreditor konkuren tidak memiliki hak in rem atas harta pailit, namun memiliki hak in personam berdasarkan konsesus dan pacta sunt servanda dengan debitor. ${ }^{15}$ Pemenuhan hak tagih kreditor konkuren berdasarkan prinsip paru pasu dan prinsip pacta sunt servanda, sehingga meskipun kreditor tidak mendapat pemberian jaminan kebendaan, demi hukum debitor berhak atas pembayaran utang. Selain itu, dalam kepailitan kreditor konkuren memiliki hak voting untuk menerima atau menolak proposal perdamaian dengan para kreditor konkuren. ${ }^{16}$ Hak voting tersebut tidak diberikan kepada kreditor separatis, kecuali telah melepaskan hak separatis dan berposisi sebagai kreditor konkuren.

Dalam melaksanakan tanggung jawabnya penanggung utang pada asasnya tidak menanggung lebih dari kewajiban kreditor dan atas pembayaran yang telah dilakukan oleh penanggung utang terhadap kreditor. Penanggung hanya dapat menanggung sesuai dengan perikatan pokok. Bahkan, penanggung dapat menanggung sebagian atau seluruhnya sesuai dengan perjanjian.

Pembayaran penanggung kepada kreditor tidak diwajibkan selain jika debitor telah wanprestasi dan benda debitor telah lebih dahulu disita dan dijual guna membayar kreditor. Ketika pembayaran oleh debitor masih belum

\footnotetext{
${ }^{13}$ Ayu anisaa dam Muhammad Adiguna Bimasakti, Kedudukan Debitor Utama dan Personal Guarantor (Guepedia 2019).[13].

${ }^{14}$ Elytas Ras Ginting, Hukum Kepailitan Teori Kepailitan (Sinar Grafika 2018).[56].

${ }^{15}$ ibid.

${ }^{16}$ ibid.[57].
} 
menutup utang kepada kreditor, dalam hal ini penanggung bertindak sebagai cadangan debitor untuk membayar utang kreditor. Penanggung telah membayar utang debitor dapat menuntut kembali pembayaran kepada debitor, baik apabila penanggungan tersebut terjadi dengan pengetahuan ataupun tanpa pengetahuan debitor. ${ }^{17}$ Hak untuk menuntut kembali pembayaran yang telah dilakukan oleh penanggung utang kepada debitor disebut hak regres. Hak regres menurut Pasal 1839 BW terbatas sesuai dengan yang dibayarkan penanggung utang kepada kreditor, diantaranya meliputi uang pokok, bunga, dan biaya-biaya sesuai yang telah dibayarkan kepada kreditor.

Hak regres akan tetap ada mesikupun tidak diperjanjikan secara khusus dalam perjanjian jaminan perorangan atau surat-surat tanda bukti lain. Hak regres timbul setelah penanggung membayar utang debitor kepada kreditor secara sukarela maupun atas putusan hakim yang memutus penanggung untuk membayar utang tersebut. ${ }^{18}$ Selain itu, hak regres diberikan baik mengenai utang pokok, bunga, maupun biaya-biaya, kerugian, dan bunga jika ada alasan untuk itu sebagaimana diatur pada Pasal 1839 ayat (4) BW.

\section{Upaya Hukum Penanggung Atas Tidak Diakuinya Hak Regres dalam Pengurusan dan Pembagian Harta Pailit}

Utang memiki makna yang penting, karena tanpa ada utang perkara kepailitan tidak dapat diajukan permohonan pernyataan pailit. Esensi kepailitan adalah melakukan likuidasi aset debitor untuk membayarkan utang pada para kreditor. Dengan demikian utang merupakan raison d'etre. Pengertian utang dalam Pasal 1 angka 6 UUK merupakan kewajiban yang dapat dinyatakan dalam jumlah uang baik dengan mata uang Indonesia maupun mata uang asing yang timbul secara langsung atau di kemudian hari. Utang merupakan salah satu unsur penting dalam syarat pengajuan kepailitan.

\footnotetext{
${ }^{17}$ ibid. [27].

${ }^{18}$ Sri Soedewi Masjchoen Sofwan, Hukum Jaminan di Indoensia: Pokok-Pokok Hukum Jaminan dan Jaminan Perorangan (Liberty Offset 2011).[100].
} 
Permohonan pernyataan pailit harus disertai dengan pembuktian dan memenuhi persyaratan pailit sebagaimana diatur pada Pasal 2 Ayat (1) jo. Pasal 8 Ayat (4) UUK. Dari ketentuan pasal 2 Ayat (1) mengenai persyaratan pailit maka dapat disimpulkan bahwa seorang debitor dapat diajukan permohonan apabila memenuhi seluruh persyaratan antara lain: ${ }^{19}$

a. Debitor memiliki paling sedikit 2 (dua) kreditor;

b. Debitor tidak membayar lunas sedikitnya 1 (satu) utang kepada salah satu kreditor;

c. Utang telah jatuh tempo dan dapat ditagih (due and payable);

d. Atas permohonan sendiri maupun 1 (satu) atau lebih kreditornya.

Dalam hal ini memungkinkan bahwa penanggung utang yang berkedudukan sebagai kreditor dapat megngajukan gugatan pailit terhadap debitor. Pengajuan gugatan kepailitan terhadap debitor tidak menutup kemungkinan bahwa debitor tersebut memiliki kreditor lain selain dari penanggung utang. Kreditor yang akan mengajukan permohonan pailit harus diwakilkan oleh advokat yang bertujuan untuk menciptakan proses sederhana dan cepat sesuai Pasal 7 Ayat (1) UUK.

Permohonan pernyataan pailit sebagaimana diatur pada Pasal 8 Ayat (4) UUK harus dikabulkan apabila terdapat fakta yang dapat dibuktikan secara sederhana bahwa syarat pada Pasal 2 Ayat (1) UUK telah terpenuhi. Pengaturan pembuktian secara sederhana dalam UUK dikenal dengan pembuktian sumir yang dalam Bahasa Belanda disebut "Summier" atau "Summerlijki" merupakan proses peradilan yang diperpendek, tanpa keterangan tertulis dari kedua belah pihak tanpa pembuktian yang diperinci.

Ketika seluruh persyaratan pailit telah terpenuhi dan dapat dibuktikan secara sederhana panitera wajib menerima pendaftaran permohonan pailit dan menyampaikan kepada ketua Pengadila. Ketika proses pemeriksaan berlangsung oleh Pengadilan Niaga, undang-undang memberikan perlindungan kepada kreditor untuk mengajukan permohonan kepada pengadilan yaitu:

a. Melakukan sita jaminan terhadap sebagian atau seluruh harta debitor;

${ }^{19}$ Sutan Remy Sjahdeini, Hukum Kepailitan Memahami Undang-Undang No.37 Tahun 2004 Tentang Kepailitan (Pustaka Utama Grafiti 2009). [52]. 
b. Menunjuk kurator sementara untuk mengawasi:

1. pengelolaan perusahaan debitor;

2. pembayaran kepada kreditor, pengaliham, atau pengagunan kekayaan debitor yang dalam kepailitan merupakan wewenang kurator;

Upaya pengamanan harta kekayaan debitor dilakukan sita jaminan sebagai upaya preventif mencegah kemungkinan debitor melakukan suatu perbuatan atas harta kekayaan dan merugikan kreditor dalam memperoleh pelunasan utang. ${ }^{20}$ Akibat hukum dari keputusan kepailitan terhadap kekayaan debitor maupun debitor antara lain:

1. Putusan pailit dapat dijalankan terlebih dahulu (putusan serta merta).

Kepailitan merupakan sitaan umum meliputi harta kekayaan debitor yang dimiliki pada saat kepailitan atau yang akan menjadi miliknya setelah pailit. ${ }^{21}$ Maka putusan kepailitan adalah serta merta dan dapat dijalankan telebih dahulu meskipun terhadap putusan kepailitan dapat dilakukan suatu upaya hukum yang berarti akibat dari putusan kepailitan berlaku secara mutatis mutandis bahwa walaupun ditempuh upaya hukum. ${ }^{22}$ Dalam melakukan pengurusan dan harta pailit yang merupakan fungsi kurator, kurator didamping oleh hakim pengawas. Perbuatan kurator dalam mengurus dan harta pailit ketika sebelum atau pada tanggal kurator menerima pemberitahuan putusan pailit dibatalkan akan berlaku sah dan mengikat debitor.

\section{Sitaan umum (Public Attachment, Gerechtelijk Beslag)}

Sitaan umum Pasal 21 UUK mengatur bahwa kepailitan meliputi seluruh harta debitor baik saat putusan kepailitan dan segala sesuatu yang diperoleh selama proses kepailitan. Tujuan dari sitaan umum adalah untuk menghentikan tindakan debitor agar tidak melakukan transasksi terhadap harta kekayaannya. Sehingga dengan adanya sitaan umum, harta debitor akan disita dan menghentikan segala transaksi dan perbuatan hukum terhadap harta kekayaan yang akan digunakan untuk pelunasan kreditor.

\footnotetext{
${ }^{20}$ ibid. [139].

${ }^{21}$ Elyta Ras Ginting, Op.Cit.[153].

${ }^{22}$ M. Hadi Shubhan, Op.Cit.[163].
} 
3. Kehilangan wewenang atas harta kekayaan

Pasal 24 UUK mengatur bahwa debitor demi hukum telah kehilangan hak untuk mengurus (daden van behooren) dan melakukan perbuatan kepemilikan terhadap harta kekayaannya (daden van beschikking). Kehilangan atas hak debitor hanya terbatas untuk kekayaannya, dan tidak termasuk terhadap status pribadi debitor. Oleh karena itu pernyatan pailit tidak menghilangkan hak keperdataan serta hak selaku warga negara baik hak politik maupun hak privat debitor.

4. Perikatan setelah pailit

Berdasarkan Pasal 25 UUK, Perikatan debitor setelah putusan pailit tidak dapat dibayarkan dari harta pailit. Apabila ketentuan ini dilanggar, maka tindakan pembayaran dari harta pailit tidak mengikat terhadap harta kekayaan, kecuali memberi keuntungan terhadap harta pailit. Perikatan ini sering dilakukan dengan perikatan yang di-antedateer (perikatan yang ditanggalkan mundur kebelakang) dan lahir kreditor fiktif demi kepentingan debitor.

5. Pembayaran piutang debitor pailit

Setelah putusan pailit, pembayaran piutang bagi debitor tidak boleh dilakukan karena berakibat tidak membebaskan utang tersebut. Serta tuntutan maupun gugatan akan hak dan kewajiban mengenai harta kekayaan harus ditujukan kepada kurator. Harta kekayaan debitor tidak dalam kewenangan debitor, dan telah beralih kepada kurator. Oleh sebab segala transaksi yang dilakukan debitor dalam menambah atau mengurangi nilai kekayaan tidak lagi ditujukan kepada debitor. Kurator merupakan pihak yang bertugas mengurus dan membereskan harta kepailitan sebagaimana telah diatur dalma Undang-Undang dan telah memiliki legal standing dalam melaksanakan kewajiban yang diantu oleh hakim pengawas.

6. Penetapan putusan pengadilan sebelumnya

Penetapan pelaksanaan pengadilan dan penyitaan terhadap harta kekayaan debitor harus dihentikan setelah ada putusan pernyataan pailit. Ketetuan ini merupakan konsekuensi logis dari sitaan umum sehingga segala sesuatu yang berkaitan dengan harta debitor harus dihentikan, maka penetapan pengadilan untuk melakukan sita jaminan harus dihentikan dengan adanya putusan pailit. Tujuan 
pemberhentian putusan pengadilan sebelumnya adalah untuk menghindari kreditor mendahului dalam mendapatkan pembayaran utang, dan melindungi kepentingan kreditor lainnya untuk mendapat pelunasan secara adil.

7. Hubungan kerja dengan para pekerja perusahaan pailit

Pekerja yang bekerja kepada debitor pailit dapat memutuskan hubungan kerja atau kurator dapat menghentikan pekerja dengan jangka waktu yang disepakati atau menurut peraturan perundang-undangan, dan pemberhentian hubungan kerja dapat dilaksanakan dengan pemberitahuan terlebih dahulu paling singkat 45 (empat puluh lima) hari.

8. Kreditor separatis dan penanggungan hak (Stay)

Ketentuan hak tangguh (stay) diatur pada Pasal 56 Ayat (2) UUK yang mengatur bahwa kreditor separatis ditangguhkan haknya untuk mengeksekusi selama 90 (Sembilan puluh) hari jaminan yang dimilikinya. Dasar filosofi ketentuan ini berdasarkan sering kali dalam praktitk dijumpai kreditor menjual jaminan kebendaan dengan cepat dan dibawah harga pasar. Tindakan tersebut hanya berdasarkan kepentingan kreditor sendiri tanpa memperhatikan kepentingan kreditor lainnya.

Oleh karena itu ditangguhkan selama 90 hari merupakan kesempatan bagi kurator untuk memperoleh harga yang terbaik dalam menjual jaminan kebendaan. Apabila nilai penjualan jaminan kebendaan melebihi piutang kreditor, maka kelebihannya dikembalikan kepada debitor dan dimasukan sebagai boedel pailit.

\section{Organ-Organ Perseroan Terbatas}

Ketentuan Undang-Undang Nomor 40 Tahun 2007 Tentang Perseroan Terbatas (UU PT) pada Pasal 79 Ayat (3) dan Pasal 96 dinilai tidak tepat karena tidak memperbolehkan debitor pailit, direktur, dan komisaris PT menjadi direksi dan komisaris perusahaan lain. Tidak tepat karena kepailitan hanya berkakibat pada kekayaan debitor, bukan berakibat pada hak subyektif. Pada hakikatnya pailit merupakan keadaan seseorang yang tidak mampu membayar utang-utang kepada para kreditor, yang mana tidak mampu membayar utang merupakan risiko yang sering terjadi. Oleh karena itu tidak sepatutnya ketentuan kepailitkan menjadi persyaratan seseorang terkendala dalam melaksanakan hak-hak subyektif. 
10. Action Pauliana dalam hukum kepailitan

Actio pauliana dalam kepailitan merujuk pada ketentuan pasal 1341 BW, namun memiliki ketentuan-ketentuan khusus. Pasal 1341 BW menyatakan bahwa kreditor dapat mengajukan mengenai tidak berlakunya tindakan yang tidak wajib dilakukan debitor namun merugikan kreditor selama dapat dibuktikan bahwa debitor menyadari bahwa akibat dari tindakannya dapat merugikan kreditor. Oleh karena itu, kreditor cukup dengan menunjukkan bahwa pada saat melakukan tindakan dapat merugikan kreditor.

Lain hal menurut hukum kepailitan, actio pauliana diajukan oleh kurator dengan persetujuan hakim pengawas. Hal ini merupakan ciri pembeda dengan actio pauliana berdasarkan Pasal 1341 BW yang diajukan oleh kreditor. Syarat gugatan actio pauliana adalah debitor dan pihak yang bersangkutan dianggap mengetahui atau sepatutnya mengetahuan bahwa perbuatan yang dilakukan dapat mengakibatkan kerugian bagi kreditor.

Pengajuan gugatan actio pauliana diajukan ke Pengadilan Niaga, tetapi dalam praktiknya jarang dikabulkan oleh hakim karena berkaitan dengan perlindungan hukum pihak ketiga yang melakukan transaksi. Apabila actio pauliana dikabulkan dapat memberikan akibat antara lain:

1. Mengembalikan barang yang diperolah dari harta kekayaan debitor;

2. Bila harga/nilai barang berkurang, maka wajib bertanggung jawab mengembalikan nilai ganti rugi;

3. Apabila barang tidak ada, maka wajib mengganti rugi nilai barang tersebut.

\section{Paksa badan (Gijzeling)}

Undang- Undang Kepailitan mengatur lembaga gijzeling pada Pasal 93 UUK sampai Pasal 96 UUK. Sedangkan ketentuan teknis gijzeling merujuk pada Peraturan Mahkamah Agung Nomor 1 Tahun 2000 tentang Lembaga Paksa Badan. Gijzeling merupakan upaya hukum yang diajukan atas usul hakim pengawas, permintaan kurator, atau permintaan kreditor untuk memastikan debitor pailit benar-benar membantu tugas kurator dalam pengurusan dan pemberesan harta. Tujuan penerapan gijzeling untuk menekan debitor agar bersikap kooperatif dalam proses kepailitan. 
Di dalam UUK tidak mengatur ketentuan minimum utang debitor pailit yang beritikad tidak baik yang dapat dilakukan gijzeling dan batasan usia debitor yang dapat dikenakan gijzeling. Berkenaan dengan ruang lingkup itikad tidak baik debitor dapat merujuk sebagaimana menurut Pasal 98 UUK, Pasal 110 UUK, atau Pasal 121 Ayat (1) dan Ayat (2) UUK.

12. Ketentuan pidana

Debitor pailit dapat dikenakan ketentuan pidana Pasal 226 KUHP dan Pasal 396 KUHP sampai 403 KUHP yang berkaitan dengan pelaksanaan pemberesan harta pailit. Berbeda dengan kepailitan perseroan terbatas yang mengenakan direksi dan/ atau komisaris sebagai pihak yang dapat dikenakan ketentuan pidana sebagaimana diatur pada Pasal 398 KUHP, Pasal 399 KUHP, dan Pasal 403 KUHP.

Berdasarkan ketentuan ini dapat disimpulkan bahwa putusan pailit tidak mutatis mutandis dengan ketentuan pidana. Kepailitan adalah keadaan debitor tidak mampu membayar utang kepada kreditor dan hanya berkaitan dengan harta kekayaan debitor yang diproses oleh kurator yang bertugas untuk mengurus dan membereskan harta pailit. Maka subyek yang dinyatakan pailit tidak sama dengan pelaku tindak pidana, karena harus memenuhi unsur-unsur perbuatan pidana sesuai KUHP. ${ }^{23}$

Penanggung dapat langsung dituntut oleh kreditor terlebih dahulu karena ada hak subrogasi yaitu penanggung menggantikan dan mengambil alih kedudukan debitor. Ketentuan ini dapat berlaku apabila penanggung telah melepaskan hak istimewa. Hak istimewa adalah hak penanggung untuk melindungi harta kekayaan yang merupakan cadangan. Hak istimewa tersebut adalah hak untuk kreditor menuntut debitor dahulu, hak menuntut pemecahan utang ketika penanggung lebih dari seorang, hak mengajukan tangkis gugat, dan hak untuk dibebaskan dari penanggungan.

Ketika penanggung telah membayarkan utang debitor kepada kreditor, kedudukan penanggung berganti sebagai kreditor. Ketentuan ini lahir berdasarkan Undang-Undang dan memberikan akibat hukum bagi kreditor baru berupa hak

\footnotetext{
${ }^{23}$ M. Hadi Shubhan, Op.Cit.[185].
} 
regres dan hak subrogasi. Hak regres dan hak subrogasi lahir secara otomatis sebagai bentuk perlindungan hukum bagi penanggung yang telah membayarkan utang debitor.

Saat penanggung telah menjadi salah satu kreditor, dan debitor dinyatakan pailit, maka tuntutan hak dan kewajiban menyangkut harta kekayaan debitor diajukan kepada curator sesuai Pasal 27 UUK. Tuntutan untuk pemenuhan suatu perikatan dari harta pailit dapat diajukan dengan mendaftar dalam pencocokan atau verifikasi piutang untuk menguji kebenaran piutang kreditor. Rapat tersebut akan dihadiri oleh hakim pengawas, para kreditor, kurator, dan debitor pailit. Kehadiran debitor pailit merupakan suatu kewajiban agar dapat memberika keterangan oleh hakim pengawas. Apabila debitor tidak hadir dengan panggilan patut, maka rapat piutang dilakukan tanpa kehadiran debitor pailit.

Apabila rapat pencocokan piutang menghasilkan bantahan piutang, maka akan ada upaya untuk mendamaikan atau memerintahkan untuk menyelesaikan ke pengadilan. Upaya banding atau pengajuan keberatan terhadap penetapan hakim pengawas diatur secara tegas pada Pasal 68 Ayat (1) UUK. Pengajuan keberatan biasanya dilakukan oleh kurator atau kreditor yang tidak puas dengan jumlah maupun peringkat utang oleh hakim pengawas. ${ }^{24}$ Upaya banding atau pengajuan keberatan atas penetapan hakim pengawas akan diperiksa oleh majelis hakim yang ditunjuk ketua pengadilan niaga. ${ }^{25}$ Prosedur pemeriksaan ini disebut renvoi prosedur. Menurut J.B. Huizink renvoi prosedur yaitu perujukan ke pengadilan tanpa adanya gugatan dan berkaitan dengan pengurusan dan pemberesan harta pailit yang bersifat bukan sengketa yang dapat diselesaikan secara damai berdasarkan asas mufakat oleh hakim pengawas dalam rapat kreditor. namun, apabila tidak mencapai mufakat maka akan dibawa untuk diperiksa oleh majelis hakim di pengadilan niaga.

Dapat dilakukan upaya hukum berupa gugatan lain-lain, apabila dalam rapat pencocokan piutang (RPP) menghasilkan bantahan piutang, yang memungkinkan bahwa kurator selaku pihak yang mengurus dan membereskan harta debitor tidak

\footnotetext{
${ }^{24}$ Elyta Ras Ginting, Op.Cit.[346].

${ }^{25}$ ibid.
} 
mengkaui piutang penanggung yang dalam hal ini adalah hak regres. Hak regres yang tidak diakui sebagai utang menimbulkan kerugian karena meniadakan perlindungan hukum bagi penanggung. Secara nyata, tindakan tidak mengakui hak regres sebagai utang dapat dikategorikan sebagai tindakan yang merugikan kreditor. Ketentuan gugatan lain-lain diatur dalam Penjeasan Pasal 3 Ayat (1) UUK yang berbunyi:

"Yang dimaksud dengan "hal-hal lain" yang antara action pauliana, perlawanan pihak ketiga terhadap penyitaan, atau perkara dimana debitor, kreditor, kurator, atau pengurus menjadi salah satu pihak dalam perkara yang berkaitan dengan harta pailit termasuk gugatan kurator terhadap direksi yang menyebabkan perseroan dinyatakan pailit karena kelalaiannya atau kesalahannya".

Hukum Acara yang berlaku dalam mengadili perkara yang termasuk "halhal lain" adalah sama dengan hukum acara perdata yang berlaku bagi perkara permohonan pernyataan pailit termasuk mengenai pembatasan jangka waktu penyelesaiannya. Perlu dibedakan antara gugatan lain-lain dengan upaya hukum kasasi maupun peninjauan kembali. Upaya hukum kasasi dan peninjauan kembali merupakan upaya hukum atas putusan pada tingkat pertama atau tingkat akhir, sehingga obyek kajiannya merupakan putusan hakim terhadap debitor. Sedangkan obyek gugatan lain-lain mengenai harta debitor yang dijatuhkan suatu PKPU atau pailit. Apabila terdapat pihak yang tidak puas dengan putusan pengadilan, maka dapat diajukan kasasi atau peninjauan kembali.

Gugatan lain-lain untuk melindungi kepentingan kreditor yang terancam dirugikan karena itikad buruk debitor yang terlepas dari gugatan renvoi dan action pauliana. Pengajuan gugatan lain-lain dilakukan oleh pihak yang memiliki hubungan relevan dengan harta debitor pailit dan terdapat batasan tidak meliputi tuntutan pidana terhadap pihak terkait.

Gugatan lain-lain dapat dilakukan oleh kurator untuk kepentingan kreditor maupun gugatan tersebut diajukan oleh pihak ketiga atau gugatan oleh kreditor dan/ atau debitor terhadap tindakan kurator yang dirasa telah melanggar hukum. gugatan ini dilakukan oleh pihak yang berkepentingan dan dalam lingkup perdata. Gugatan lain-lain yang diajukan oleh kreditor kepada kurator dapat berdasarkan perbuatan melanggar hukum (PMH) sesuai dengan Pasal 1365 BW. 


\section{Kesimpulan}

Hak regres adalah bentuk perlindungan hukum bagi penanggung utang yang diberikan menurut ketentuan Pasal 1339 BW untuk melindungi hak penanggung utang untuk mendapatkan kembali pembayaran yang telah dilakukan kepada kreditor atas utang debitor. Setelah penanggung utang melakukan pembayaran, secara otomatis melahirkan hak regres bagi penanggung utang. Hak untuk menuntut kembali pembayaran yang telah dilakukan dapat diklasifikasikan sebagai piutang penanggung utang. Sehingga penanggung utang yang telah berkedudukan sebagai kreditor dapat menuntut hak regres tersebut kepada debitor.

Renvoi prosedur adalah bentuk perlindungan hukum yang diberikan oleh Undang-Undang nomor 34 tahun 2004 tentang Kepailitan dan Penundaan Kewajiban Pembayaran Utang kepada para kreditor untuk melindungi hak-hak para kreditor atas tagihan yang mereka ajukan kepada kurator sehubungan dengan kepailitan debitor. Apabila ada perselisihan atau bantahan atas tagihan yang diajukan oleh kurator maka perselisihan atau bantahan tersebut harus diselesaikan melalui renvoi prosedur sesuai ketentuan Pasal 127 Ayat (1) UU No.37 tahun 2004 UUK. Jika bantahan atau perselisihan tidak dapat diselesaikan oleh hakim pengawas, maka hakim pengawas memerintahkan perselisihan atau bantahan diselesaikan di pengadilan negeri dimana pemeriksaan dan/atau pembuktian harus dilakukan secara cepat dan sederhana. Para pihak yang berselisih tidak perlu dipanggil secara resmi oleh pengadilan, namun pihak yang mengajukan harus menghadiri persidangan. Majelis hakim akan memeriksa secara sederhana dan memberikan putusan dalam waktu singkat sejak renvoi prosedur diajukan oleh pihak yang berkepentingan.

\section{Daftar Bacaan}

\section{Buku}

Agus Yudha Hernoko, Hukum Perjanjian Asas Proporsionalitas dalam Kontrak Komersial (Kencana 2010).

Ahmadi Miru, dan Sakka Pati, Hukum Perikatan Penjelasan Makna Pasal 1233 sampai 1456 BW (RajaGrafindo Persada 2008). 
Ayu Anisaa, dan Muhammad Adiguna Bimasakti, Kedudukan Debitor Utama dan Personal Guarantor (Guepedia 2019).

M. Hadi Subhan, Hukum Kepailitan, Prinsip, Norma, dan Praktik di Peradilan, (Fajar Interpratama Mandiri 2008).

Sri Soedewi Masjchoen Sofwan, Hukum Jaminan di Indoensia: Pokok-Pokok Hukum Jaminan dan Jaminan Perorangan (Liberty Offset 2011).

Subekti dan R. Tjitrosudibyo, Kitab Undang-Undang Hukum Perdata-Burgerijk Wetboek (Balai Pustaka 2014).

Sutan Remy Sjahdeini, Hukum Kepailitan Memahami Undang-Undang No.37 Tahun 2004 Tentang Kepailitan (Pustaka Utama Grafiti 2009).

Trisadini Prasastinah Usanti, dan Leonora Bakarbessy, Buku Refrensi Hukum Perbankan Hukum Jaminan (Revka Petra Media 2014).

\section{Jurnal}

Sarah D.L. Roeroe, 'Kewenangan Pihak Ketiga Sebagai Penjamin Dalam Perjanjian Kredit' (2017) 1 Lex Privatum.

Annisa Amalia Rachmah, 'Analisis Yuridsi Pernjaminan Perorangan (Personal Guarantee) pada Kepailitan Perseroan Terbatas' (2016) 5 Diponegoro Law Jurnal.

\section{Perundang-undangan}

Undang-Undang Nomor 7 Tahun 1992 tentang Perbankan (Lembaran Negara dan Tambahan Lembaran Negara Tahun 1992).

Undang-Undang Nomor 10 Tahun 1998 tentang Perubahan Atas Undang-Undang Nomor 7 Tahun 1992 tentang Perbankan (Lembaran Negara Republik Indonesia Tahun 1998 Nomor 182, Tambahan Lembaran Negara Repubik Indonesia Nomor 3790).

Undang-Undang Nomor 37 Tahun 2004 tentang Kepailitan dan Penundaan Kewajiban Pembayaran Utang (Lembaran Negara Republik Indonesia Tahun 2004 Nomor 131, Tambahan Lembaran Negara Republik Indonesia Nomor 4443).

Undang-Undang Nomor 40 Tahun 2007 tentang Perseroan Terbatas (Lembaran Negara Republik Indonesia Tahun 2007 Nomor 106, Tambahan Lembaran Negara Republik Indonesia Nomor 4756). 
1834 Madeleine Celandine: Hak Regres Penanggung...

--halaman ini sengaja dibiarkan kosong-- 